\title{
Effectiveness of NSAIDs and Physiotherapy in Acute Low Back Pain on Pain and Function in Workers of Pakistan Textile Industry
}

\author{
Imran Ghafoor, Tahirah Kalsoom, Awais Gohar, Akhtar Rasul
}

\begin{abstract}
Objective: To determine the effective treatment option in acute low back pain in workers of textile industry of Pakistan.

Methodology: A descriptive cross sectional study from March 208 to August 2018 was conducted at social security hospital Islamabad. Sixty (60) patients with acute low back pain were recruited in the study. They were divided into two groups of thirty (30) each. All the patients filled self-reported questionnaire which includes Oswestry Disability index (ODI), and Visual Analogue scale (VAS). All the outcome measures were taken at baseline and 2 weeks follow up.

Results: The mean age of NSAIDs group was $32 \pm 7.72$ and mean age of NSAIDs \& Physio group was $33 \pm 9.93$ years. The baseline ODI was $13.50 \pm 7.29$, and after two weeks for ODI were $9.63 \pm 7.33$. The NSAIDs and Physio group showed statistically significant for the ODI after two weeks $(p<0.05)$ and VAS after two weeks treatment follow up $(p<0.05)$.

Conclusion: It was concluded that NSAIDs along with physiotherapy is more effective then NSAIDs alone. The LBP was significantly associated with smoking, sleep disturbance, education (Primary), work shift (day shift) and type of labor (unskilled).
\end{abstract}

Key Words: Low back pain, NSAIDs, Visual analogue scale, Manual material handling.

This article may be cited as: Ghafoor I, Kalsoom T, Gohar A, Rasul A. Effectiveness of NSAIDs and Physiotherapy in Acute Low Back Pain on Pain and Function in Workers of Pakistan Textile Industry. J Liaquat Uni Med Health Sci. 2019;18(04):320-4. doi: 10.22442/jlumhs.191840650

\section{INTRODUCTION}

Low back pain (LBP) is the leading cause of disability and absence from the work place all over the world. It is a common reason for hospital visits in America. About one quarter adults reported LBP in U.S.A ${ }^{1}$.

Absents from work affects the productivity and costs the health care. In 2006 the estimated cost was $\$ 100$ billion in USA for LBP hospital care. The pain on lumber region (L1-L5) vertebra is taken as low back area, and pain in this region is sometime says low back pain. Acute LBP persists less than 4 weeks and may be due to the muscle spasm, disc pathology or facet joint syndrome ${ }^{2}$. Manual material handling (MMH) workers are more prone to develop LBP due to the wrong biomechanics and ergonomics ${ }^{3}$. Repetitive trunk flexion movement, spinal loading, manual material handling and vibration are the common risk factors for LBP in workers in all sectors. In textile industry, the workers are more prone to spinal loading and $\mathrm{MMH}$ with wrong biomechanics and ergonomics ${ }^{4}$. There is a lack of biomechanical and ergonomic evaluation of ourindustry ${ }^{5}$. Non-steroidal antiinflammatory drugs (NSAIDs) have shown moderate effects of pain improvement in acute low back patients. ${ }^{6}$ Liddle SD $2007^{7}$ demonstrated the postural education for acute low back pain. They suggested that physical therapy and functional activities are helpful in low back pain. Early physiotherapy is beneficial for low back pain.

A physical therapist may play important role in minimizing the low back pain risk factors by posture education in workers. In order to reduce the musculoskeletal risk factors a physical therapist should be engaged in industries and dispensaries for patient education about material handling, and to teach correct ergonomics.

Physiotherapy is much effective in chronic low back pain. It is one of the interventions which enhance the function and minimize pain in musculoskeletal injuries. The rational of this study was to investigate the effectiveness of physiotherapy in acute low back pain in patients who were textile industry workers. Physiotherapy approach was expected to reduce the dependence on medicine for relieving pain.

\section{METHODOLOGY}

A short survey was conducted at social security hospital Islamabad, Pakistan from March 2018 to August 2018 and study was approved by the institutional review board. Sixty (60) patients with acute LBP participated in the study and signed the consent form. Patients had low back pain were 
recruited in the study and divided into two groups. Convenient sampling technique was used for patient's selection. The patients between 20-60 years of age of both gender groups were included in the study. Patients having acute LBP with pain and dysfunction were included. Patients having Oswestry disability index $>20$ were included. Patients with pain $>4$ on VAS (Visual Analogue scale) working in Pakistan textile industry were included only. Patients with acute onset of low back pain were included. Patients having any lumber spine surgery, tumor history, fracture, spondyloarthropathy, and congenital anomaly were excluded. Red flags to SWD (short wave diathermy) like tumor, metal in body and heat sensitivity were excluded. Contraindication of NSAIDs drugs and patients with history of kidney pain were excluded.

All the Patients of acute low back pain were assessed by orthopedic surgeon and referred to physiotherapy department for physiotherapy treatment. Oral NSAIDs were recommended by orthopedic surgeon. There were two groups under treatment. The group 1 included NSAIDs with Physiotherapy and group 2 include only NSAIDs treatment. In oral NASIDs either Diclofenac sodium $50 \mathrm{mg}$ or Diclofenac Potassium $50 \mathrm{mg}$ was used along with muscle relaxant (orphenadrine50mg, Tizanidine $2 \mathrm{mg}$ ).In oral NSAIDs treatment group, NSAIDs were recommended two times a day for 5 days along with muscle relaxants, with any combination of above mentioned salts ${ }^{8}$.

In physiotherapy session, short wave diathermy (SW$400 \mathrm{~S}$, ITO Japan) was given at low back area with co -planner method by using large capacitor electrode for 15 minutes $^{9}$. Sustained stretching exercise of gluteus muscle, hamstring muscles and erector spinae was given for 30 seconds with 10 repetitions of 2 sets. Strengthening exercise of lumber extensors with 10 repetitions of 2 sets $^{10}$. Patient education for postural correction was also given at end of the session. Data was collected with the help of self-reported questionnaire which included Oswestry Low Back Pain Disability Questionnaire (ODI), and Visual Analogue scale (VAS). All the outcome measures were taken at baseline and 2 weeks follow up. IBM SPSS 20.0 software was used for data analysis. Descriptive statistics was used for frequency counts to summarize the information. Paired sample t-Test was used to compare the baseline demographics and between groups treatment effects, Alpha level of significance was 0.05 . The study was approved from institutional review board.

\section{RESULTS}

Sixty (60) patients of low back pain were assessed for eligibility. They were divided into two groups of thirty (30) each. The mean age of NSAIDs group was
$32 \pm 7.72$ and mean age of NSAIDs \& Physio group was $33 \pm 9.93$ years. There were $28(93.3 \%)$ male and 2 $(6.7 \%)$ female in NSAIDs group and $25(83.3 \%)$ male and $5(16.7 \%)$ female in NSAIDs and Physio group. The baseline ODI was 13.50 with SD 7.29 , and VAS was 2.33 with SD 0.889 . The results after two weeks for ODI were 9.63 with SD 7.33 and VAS were 1.20 with SD 0.924 . The $56.7 \%$ patients were used Diclofenac sodium \&Tizanidine in group 1 and $50 \%$ patients used Diclofenac sodium \&Tizanidine in group 2. The demographic and work related information was collected from two groups (Table I). The NSAIDs and Physio group shows statistically significant for the ODI after two weeks $13.5 \pm 7.2(p<0.05)$ and VAS after two weeks treatment follow up $2.3 \pm .83(p<0.05)$. (Table II)

\section{TABLE I: DEMOGRAPHIC AND WORK RELATED INFORMATION IN PAKISTAN TEXTILE INDUSTRY WORKERS $(n=60)$}

\begin{tabular}{|c|c|c|}
\hline Variables & $\begin{array}{l}\text { NSAIDs \& Physio } \\
\text { Group }(n=30)\end{array}$ & $\begin{array}{l}\text { NSAIDs Group } \\
(n=30)\end{array}$ \\
\hline Age (year) & $33 \pm 9.93$ & $32 \pm 7.72$ \\
\hline Gender (m) & $28(93.3 \%)$ & $25(83.3 \%)$ \\
\hline Gender (f) & $2(6.66 \%)$ & $5(16.66 \%)$ \\
\hline $\mathrm{BMI}(\mathrm{Kg} / \mathrm{m} 2)$ & $28.56 \pm 2.58$ & $28.13 \pm 1.63$ \\
\hline $\begin{array}{l}\text { Duration of LBP } \\
\text { 1-2days } \\
\text { 3-4days } \\
\text { 5-7days }\end{array}$ & $\begin{array}{r}8(26.6 \%) \\
10(33.3 \%) \\
12(40 \%)\end{array}$ & $\begin{array}{r}3(10 \%) \\
15(50 \%) \\
12(40 \%)\end{array}$ \\
\hline $\begin{array}{l}\text { Location of LBP } \\
\text { Whole low back reg. } \\
\text { Right side of back } \\
\text { Left side of back } \\
\text { Low back with sacral } \\
\text { reg. }\end{array}$ & $\begin{array}{r}12(40 \%) \\
4(13 \%) \\
4(13 \%) \\
10(33 \%)\end{array}$ & $\begin{array}{r}19(63.3 \%) \\
2(6.7 \%) \\
2(6.7 \%) \\
7(23.3 \%)\end{array}$ \\
\hline $\begin{array}{l}\text { Pain Radiation } \\
\text { Radiation to hip } \\
\text { Radiation to knee } \\
\text { Radiation to toe } \\
\text { No radiation }\end{array}$ & $\begin{array}{r}8(26.7 \%) \\
6(20 \%) \\
4(13 \%) \\
12(40 \%)\end{array}$ & $\begin{array}{r}5(16.7 \%) \\
4(13 \%) \\
3(10 \%) \\
18(60 \%)\end{array}$ \\
\hline $\begin{array}{l}\text { Type of NSAIDs + } \\
\text { Muscle Relaxants } \\
\text { Diclofenic sodium } \\
\text { \&Tizindine } \\
\text { Diclofenic Potassium } \\
\text { \&Tizindine } \\
\text { Diclofenic sodium } \\
\text { \&Ophedramine citrate }\end{array}$ & $\begin{array}{r}17(56.7 \%) \\
9(29.3 \%) \\
4(13 \%)\end{array}$ & $\begin{array}{l}15(50 \%) \\
8(26.7 \%) \\
7(23.3 \%)\end{array}$ \\
\hline Smoker & $8(26.6 \%)$ & $11(36.7 \%)$ \\
\hline $\begin{array}{l}\text { Employment Status } \\
\text { Full time }(8 \mathrm{~h}) \\
\text { Part time }(4 \mathrm{~h}) \\
\text { Overtime }(12 \mathrm{~h})\end{array}$ & $\begin{array}{r}23(76.7 \%) \\
1(3.3 \%) \\
6(20 \%)\end{array}$ & $\begin{array}{r}27(90 \%) \\
3(10 \%)\end{array}$ \\
\hline
\end{tabular}




\begin{tabular}{|l|r|r|}
\hline Work shift & $22(73.3 \%)$ & $24(80 \%)$ \\
Day shift & $8(26.7 \%)$ & $6(20 \%)$ \\
Night shift & & \\
\hline Sleep duration & $2(6.7 \%)$ & $3(10 \%)$ \\
4hour & $15(50 \%)$ & $13(43.3 \%)$ \\
Chour & $13(43.3 \%)$ & $11(36.7 \%)$ \\
8hour & & $3(10 \%)$ \\
$>1$ ohour & $14(46.7 \%)$ & $15(50 \%)$ \\
\hline Education & $4(13.3 \%)$ & $2(6.7 \%)$ \\
Primary & $8(26.7 \%)$ & $9(30 \%)$ \\
Middle & $1(3.3 \%)$ & $3(10 \%)$ \\
High & $310 \%)$ & $1(3.3 \%)$ \\
Only know reading & & \\
Illiterate & $21(70 \%)$ & $25(83.3 \%)$ \\
\hline Labor type & $9(30 \%)$ & $5(16.7 \%)$ \\
Unskilled worker & & \\
Skilled worker & & \\
\hline
\end{tabular}

people were at more risk of developing low back pain. Unskilled workers $25(83 \%)$ were more prone to low back pain due to wrong handling of the load. Another factor related to low back pain was education of the workers, as less educated $38(63.3 \%)$ worker did not understand the manual load handling ergonomics. These results were same with another cross sectional study done by Wang $\mathrm{M}$ et $\mathrm{al}^{11}$ which demonstrated the risk factors associated with low back pain in taxi drivers. Work related factors were associated with increase low back pain. In our study day shift workers were more prone to have low back pain as compared to previous study of Meng $\mathrm{F}$ et $\mathrm{al}^{12}$. Our study shows the better results with NSAIDs and Physiotherapy as compared to NSAIDs alone. Physiotherapy techniques like stretching exercise increase the length of shorted muscles which helps in normal functional mobility of

TABLE II: PRE \& POST TREATMENT COMPARISON IN TERMS OF PAIN (VAS) AND FUNCTION (ODI)

\begin{tabular}{|c|c|c|c|c|c|c|c|c|}
\hline \multicolumn{9}{|c|}{ Paired Differences } \\
\hline \multirow{2}{*}{\multicolumn{2}{|c|}{ Study Group }} & \multirow{2}{*}{ Mean } & \multirow{2}{*}{$\begin{array}{l}\text { Std. } \\
\text { Deviation }\end{array}$} & \multirow{2}{*}{$\begin{array}{l}\text { Std. } \\
\text { Error } \\
\text { Mean }\end{array}$} & \multicolumn{2}{|c|}{$\begin{array}{l}95 \% \text { Confidence Inter- } \\
\text { val of the Difference }\end{array}$} & \multirow[t]{2}{*}{$\mathrm{t}$} & \multirow{2}{*}{$\begin{array}{l}\text { Sig. } \\
\text { (2-tailed) }\end{array}$} \\
\hline & & & & & Lower & Upper & & \\
\hline \multirow{2}{*}{$\begin{array}{l}\text { NSAIDs \& } \\
\text { Physio Group }\end{array}$} & $\begin{array}{l}\text { VAS at Baseline - VAS } \\
\text { after } 2 \text { weeks }\end{array}$ & 2.33333 & .88409 & .16141 & 2.00321 & 2.66346 & 14.456 & .000 \\
\hline & $\begin{array}{l}\text { ODI at Baseline - ODI } \\
\text { after } 2 \text { weeks }\end{array}$ & 13.5000 & 7.29549 & 1.33197 & 10.7758 & 16.2241 & 10.135 & .000 \\
\hline \multirow{2}{*}{$\begin{array}{l}\text { NSAIDs } \\
\text { Group }\end{array}$} & $\begin{array}{l}\text { VAS at Baseline - VAS } \\
\text { after } 2 \text { weeks }\end{array}$ & 1.20000 & .92476 & .16884 & .85469 & 1.54531 & 7.107 & .007 \\
\hline & $\begin{array}{l}\text { ODI at Baseline - ODI } \\
\text { after } 2 \text { weeks }\end{array}$ & 9.63333 & 7.33665 & 1.33948 & 6.8937 & 12.3728 & 7.192 & .009 \\
\hline
\end{tabular}

\section{DISCUSSION}

There was a substantial improvement in both groups in terms of pain and function. The NSAIDs \& Physio group shows statistically significant $(p<0.05)$ improvement over NSAIDs group in terms of pain and function. The improvement in NSAIDs group was also significant but other group proceeded. The NSAIDs \& Physio group was clinically significant in term of pain, VAS $(p<0.05)$, and in term of function, ODI $(p<0.05)$.Major strength of this study was that it represented low back pain in the textile industry workers of Rawalpindi and Islamabad region of Pakistan. Our study showed that NSAIDs with physiotherapy treatment by using stretching exercise and short wave diathermy (SWD) was more effective treatment option over NSAIDs alone.

There were risk factors (work shift) associated with low back pain, which may increase the incidence of low back pain. The increased BMI 28.56 \pm 2.58 was associated with low back pain. Day work shift $24(80 \%)$ muscular system. The shortwave diathermy which is a heating modality, warm up the muscles and related soft tissues and to minimizes the pain and improve function in low back pain patients ${ }^{13}$. Stretching exercise were effective with other techniques to improve function in low back pain by Grunnesjö MI $2011^{14}$.

Lau PM $2008^{15}$, in his study revealed that early physiotherapy with medicine was effective treatment option in low back people. Oliveira CB et al ${ }^{16}$ in 2018 demonstrated that physiotherapy and NSAIDs were effective combination therapy option in low back pain, and our study has shown same results. Takashi $\mathrm{N}$ $2017^{17}$ proved that NSAIDs was effective in low back patients in terms of pain but not in terms of function. Yusuf $S 2017^{18}$ in their study demonstrated that, NSAIDs with aerobic exercise is much effective then NSAIDs alone in low back pain, our study also shows the NSAIDs with physiotherapy is effective in terms of pain and function. 


\section{CONCLUSION}

It was concluded that NSAIDs along with physiotherapy is more effective then NSAIDs alone. The LBP was significantly associated with smoking, sleep disturbance, education (Primary schooling), work shift (day shift) and type of labor (unskilled worker). This is a single center study, large scale studies are recommended. This study focuses the textile industry alone, future studies in other industrial sectors are recommended. Follow up period of the study should be large for future studies.

Ethical permission: The University of Lahore IRB permission letter No. IRB-UOL/210817/ 0842. Dated: 17-02-2018

Conflict of interest: Authors of the study have no conflict of interest to declare.

Funding: There was no any funding agency.

\section{REFERENCES}

1. Deyo RA, Mirza SK. Herniated lumbar intervertebral disk. New Engl J Med. 2016; 374 (18): 1763-72. doi: 10.1056/NEJMcp1512658.

2. Katz JN. Lumbar disc disorders and low-back pain: socioeconomic factors and consequences. J Bone Joint Surg Am. 2006; 88(Suppl 2): 21-4.

3. Gooyers CE, McMillan RD, Howarth SJ, Callaghan JP. The impact of posture and prolonged cyclic compressive loading on vertebral joint mechanics. Spine (Phila Pa 1976). 2012; 37 (17): E1023-9. doi: 10.1097/BRS.0b013e318256 f9e6.

4. Griffith LE, Shannon HS, Wells RP, Walter SD, Cole DC, Côté $P$, et al. Individual participant data meta-analysis of mechanical workplace risk factors and low back pain. Am J Public Health. 2012; 102(2): 309-18. doi: 10.2105/AJPH.2011.300343.

5. Lei L, Dempsey PG, Xu JG, Ge LN, Liang YX. Risk factors for the prevalence of musculoskeletal disorders among Chinese foundry workers. Int $\mathrm{J}$ Indust Ergonom. 2005; 35(3): 197-204.

6. Roelofs PD, Deyo RA, Koes BW, Scholten RJ, van Tulder MW. Nonsteroidal anti-inflammatory drugs for low back pain: an updated Cochrane review. Spine (Phila Pa 1976). 2008; 33(16): 1766 -74. doi: 10.1097/BRS.0b013e31817e69d3.

7. Liddle SD, Gracey JH, Baxter GD. Advice for the management of low back pain: a systematic review of randomised controlled trials. Man Ther. 2007; 12(4): 310-27.

8. Slavici A, Rauschmann M, Fleege C.
Conservative management of osteoporotic vertebral fractures: an update. Eur J Trauma Emerg Surg. 2017; 43(1): 19-26. doi: 10.1007/s 00068-016-0747-5.

9. Ostrowski J, Ely C, Evans H, Bocklund D. Comparison of Pulsed Shortwave Diathermy and Continuous Shortwave Diathermy Devices. Athletic Training Sports Health Care. 2016; 8(1): 18-26. doi:10.3928/19425864-20151119-04

10. Park KN, Kwon OY, Yi CH, Cynn HS, Weon JH, $\mathrm{Kim} \mathrm{TH}$, et al. Effects of motor control exercise vs muscle stretching exercise on reducing compensatory lumbopelvicmotions and low back pain: a randomized trial. J Manipulative Physiol Ther. 2016; 39(8): 576-85. doi: 10.1016/j.jmpt. 2016.07.006.

11. Wang M, Yu J, Liu N, Liu Z, Wei X, Yan F, et al. Low back pain among taxi drivers: a cross-sectional study. Occup Med (Lond). 2017; 67(4): 290-5. doi:10.1093/occmed/ kqx041.

12. Meng F, Li S, Cao L, Li M, Peng Q, Wang C, et al. Driving fatigue in professional drivers: a survey of truck and taxi drivers. Traffic Inj Prev. 2015; 16(5): 474-83. doi: 10.1080/15389588.2014.973945.

13. Bussières $A E$, Stewart $G$, Al-Zoubi $F$, Decina $P$, Descarreaux M, Haskett $D$, et al. Spinal manipulative therapy and other conservative treatments for low back pain: a guideline from the Canadian Chiropractic Guideline Initiative. J Manipulative Physiol Ther. 2018 May 1;41(4):26593. doi: 10.1016/j.jmpt.2017.12.004.

14. Grunnesjö MI, Bogefeldt JP, Blomberg SI, Strender LE, Svärdsudd KF. A randomized controlled trial of the effects of muscle stretching, manual therapy and steroid injections in addition to 'stay active' care on health-related quality of life in acute or subacute low back pain. Clin Rehabil. 2011 Nov;25(11):999-1010. doi: 10.1177/ 0269215511403512.

15. Lau PM, Chow DH, Pope MH. Early physiotherapy intervention in an accident and emergency department reduces pain and improves satisfaction for patients with acute low back pain: a randomised trial. Aust $\mathrm{J}$ Physiother. 2008; 54(4): 243-9.

16. Oliveira CB, Maher CG, Pinto RZ, Traeger AC, Lin $\mathrm{CC}$, Chenot JF, et al. Clinical practice guidelines for the management of non-specific low back pain in primary care: an updated overview. Eur Spine J. 2018; 27(11): 2791-2803. doi: 10.1007/s00586018-5673-2.

17. Takahashi N, Omata JI, Iwabuchi M, Fukuda H, 
Shirado $O$. Therapeutic efficacy of nonsteroidal anti-inflammatory drug therapy versus exercise therapy in patients with chronic nonspecific low back pain: a prospective study. Fukushima J Med Sci. 2017; 63(1): 8-15. doi: 10.5387/fms.2016-12.

18. Yusuf S, Abdullah A, Ismaila S. Effects of non-steroidal anti-inflammatory drugs (NSAIDS) aerobic exercise and combination therapy in the management of low-back pain in Kano metropolis Kano Nigeria. Int J Physical Educ Sports Health. 2017; 4(2): 301-304.

\section{AUTHOR AFFILIATION:}

Imran Ghafoor (Correspondence Author)

Department of Physiotherapy

Social Security Hospital

Multan Road, Lahore, Punjab-Pakistan.

Email: imran.ghafoor64@gmail.com

\section{Tahirah Kalsoom}

Research Scholar

King Edward Medical University

Lahore, Punjab-Pakistan.

\section{Awais Gohar}

Director Health Services and Medical Personal

Punjab Employees Social Security Institutions

Lahore, Punjab-Pakistan.

\section{Akhtar Rasul}

Department of Physiotherapy

Sargodha Medical College, Sargodha, Punjab-Pakistan. 